\title{
Otolith-based growth reconstructions in young-of- year Atlantic silversides Menidia menidia and their implications for sex-selective survival
}

\author{
Julie W. Pringle, Hannes Baumann* \\ University of Connecticut, Department of Marine Sciences, 1080 Shennecossett Road, Groton, CT 06340, USA
}

\begin{abstract}
We examined the utility of otolith microstructure analysis in young-of-year (YoY) Atlantic silversides Menidia menidia, an important annual forage fish species along the North American Atlantic coast. We first compared the known hatch window of a local population (Long Island Sound, USA) to otolith-derived hatch distributions, finding that YoY collected in October were reliably aged, whereas survivors from November and December were progressively underaged, likely due to the onset of winter ring formation. In all collections, males outnumbered females, and both sexes had bimodal size distributions. However, while small and large females were almost evenly represented ( 60 and $\sim 40 \%$, respectively), over $94 \%$ of all males belonged to the small size group. We then examined increment widths as proxies for somatic growth, which suggested that bimodal size distributions resulted from 2 distinct slow- and fast-growing YoY phenotypes. Length back-calculations of October YoY confirmed this, because fast- and slow-growing phenotypes arose within common bi-weekly hatch intervals. We concluded that the partial sexual size dimorphism in this population resulted largely from sex-specific growth differences and not primarily from earlier female than male hatch dates, as predicted by the well-studied phenomenon of temperature-dependent sex determination (TSD) in this species. Furthermore, observed sex ratios were considerably less male-biased than reconstructed thermal histories and published laboratory TSD values predicted. Assuming that selective mortality is generally biased against slower growing individuals, this process would predominantly remove male silversides from the population and explain the more balanced sex ratios at the end of the growing season.
\end{abstract}

KEY WORDS: Temperature-dependent sex determination - Sex ratio $\cdot$ Winter ring formation · Temperature-dependent growth

\section{INTRODUCTION}

Marine fish typically experience high non-random mortalities during their first year of life, which determine the phenotypic characteristics of survivors - a long-standing research focus in fisheries ecology (Peterson \& Wroblewski 1984, Anderson 1988, Bailey \& Houde 1989). Natural mortality and selection may be particularly severe in forage fishes, whose fundamental ecological role is to channel planktonic productivity upwards in the marine food web by acting as universal prey for diverse piscivores. One such for-

\footnotetext{
*Corresponding author: hannes.baumann@uconn.edu
}

age species is the Atlantic silverside Menidia menidia (Atherinopsidae), a small $(<14 \mathrm{~cm})$ schooling fish occurring in abundance in nearshore habitats along the North American Atlantic coast and an important experimental model in evolutionary and marine ecology (Conover \& Ross 1982, Middaugh et al. 1987). Experiments on this species discovered co- and countergradient latitudinal adaptations in the ocean (Conover \& Heins 1987, Conover \& Present 1990, Conover et al. 2009), provided the first experimental proof of fisheries-induced evolution (Conover \& Munch 2002, Therkildsen et al. 2019), and quantified potential

CC The authors 2019. Open Access under Creative Commons by Attribution Licence. Use, distribution and reproduction are unrestricted. Authors and original publication must be credited. 
effects of predicted ocean warming, acidification, and oxygen decline (Depasquale et al. 2015, Murray et al. 2017, Baumann et al. 2018).

Famously, laboratory studies also revealed that sex in this species is not determined strictly at fertilization, but at least partially by environmental conditions experienced later during the larval stage (Conover \& Fleisher 1986), where higher rearing temperatures result in increasingly male-biased sex ratios (Conover \& Heins 1987). Temperature-dependent sex determination (TSD) presumably evolved in this annual species to produce females earlier in the season than males, to afford them a longer growing season leading to larger body size and thus conferring increased fitness via higher fecundity (Conover 1984). Furthermore, while northern silverside populations spawn, grow, and generally remain in nearshore waters of bays and estuaries during spring, summer, and fall, they migrate offshore during winter (Middaugh et al. 1987), when larger female size increases the likelihood of survival (Conover \& Ross 1982, Schultz et al. 1998). Given the existence and direction of TSD in silversides, one would predict that females surviving until the end of their first growing season are larger than males because they hatched earlier. This prediction has not yet been explicitly tested, perhaps because it requires detailed reconstructions of sexspecific age and growth in young-of-year (YoY) survivors. It is therefore unknown whether actual patterns of sex dimorphism and sex ratios in the field are strictly due to TSD or if they become modified by seasonal environmental changes and severe predation mortalities (Peterson \& Wroblewski 1984, Lankford et al. 2001, Friedland et al. 2015). Silverside offspring have an estimated $0.04 \%$ probability to survive to adulthood every year (Conover 1984).

The general tool of choice for reconstructing individual-based age and growth patterns in larval and juvenile fish is otolith microstructure analysis (Stevenson \& Campana 1992, Otterlei et al. 2002, Baumann et al. 2006, 2008, Gagliano et al. 2007). However, its applicability ceases for most species after the onset of winter ring formation that renders daily increments indiscernible. Previous otolith studies on $M$. menidia and $M$. beryllina focused on larval and early juvenile stages (Barkman 1978, Barkman \& Bengtson 1987), for which sex cannot be reliably identified. One otolith-based study found sex-specific hatch differences in early juvenile Atlantic silversides, while also reporting difficulties in ageing older juveniles (Conover 2004, D. O. Conover unpubl. data).

This study re-examined the utility of otolith microstructure analysis in older YoY Atlantic silversides.
We sampled survivors at the end of their growing season (October-December) and compared their otolith-derived hatch distributions with the expected hatch window of the population in our study area $\left(41^{\circ} \mathrm{N}\right.$, eastern Long Island Sound). We hypothesized that TSD would lead to larger and older females than males, i.e. females should have earlier otolith-derived hatch dates. We used increment widths as proxies for somatic growth to test for sex-specific growth differences in YoY survivors. Finally, continuous temperature records from the study site enabled the reconstruction of the survivors' thermal history during their sex-determining size window (8-21 mm; Conover \& Fleisher 1986), which allowed testing whether actual YoY sex ratios were accurately predicted by temperature-specific sex ratios observed in published laboratory trials (Conover \& Heins 1987).

\section{MATERIALS AND METHODS}

\subsection{Sampling and otolith analyses}

YoY Atlantic silversides Menidia menidia were collected from Mumford Cove $\left(41.32^{\circ} \mathrm{N}, 72.02^{\circ} \mathrm{W}\right)$ (Fig. S1 in the Supplement at www.int-res.com/ articles/suppl/m632p193_supp.pdf), a small, saltmarsh dominated embayment in eastern Long Island Sound (Connecticut, USA; $0.5 \mathrm{~km}^{2}, 1-3 \mathrm{~m}$ depth; Vaudrey et al. 2010). From a bi-weekly beach seine survey $(30 \times 2 \mathrm{~m}$ seine with $3 \mathrm{~mm}$ mesh), 3 samples on 23 October, 20 November, and 18 December 2015 were used (Table 1). These fall dates all occurred several months after the end of the assumed spawning season (May-July; Murray et al. 2014), thus maximizing the quantitative sampling of YoY survivors, minimizing mortality bias in hatch distributions, and reducing the likelihood of capturing spawned-out adults of this annual species (Conover \& Kynard 1984). On each date, samples were pooled from 2 independent seine casts. All silversides were euthanized, enumerated, measured for total length (TL) to the lower $5 \mathrm{~mm}$ and preserved frozen $\left(-20^{\circ} \mathrm{C}\right)$.

From each collection, 100 individuals were selected for otolith microstructure analysis using a TLstratified random sampling design (Table 1). For each individual, we again measured TL (nearest $0.1 \mathrm{~mm}$ ) and determined sex via visual inspection of gonads before extracting both sagittal otoliths. Sagittae were mounted on microscope slides using CrystalBond 509 ${ }^{\mathrm{TM}}$ thermoplastic cement. If equally suitable, the left or right sagitta was randomly chosen for analysis. Otoliths were hand-polished using 9 then $3 \mu \mathrm{m}$ lap- 
Table 1. Beach seine collections of young-of-year Atlantic silversides in Mumford Cove in fall 2015, including total catches in numbers $(\mathrm{N})$ and wet weight $\left(W_{\mathrm{w}}\right)$. Sex-specific means $\pm \mathrm{SD}$ of total length $(\mathrm{TL})$, age (days post hatch, dph), hatch dates, and sample sizes used for otolith microstructure analysis $\left(\mathrm{n}_{\text {oto }}\right)$ are given for small and large TL groups used throughout the study. The \% of catch was scaled based on sex ratios per $10 \mathrm{~mm}$ TL class in the otolith sample; mean age and hatch date were scaled to population

\begin{tabular}{|c|c|c|c|c|c|c|c|}
\hline Collection date & $\begin{array}{c}\text { Catch } \\
\left(\mathrm{N}_{i} W_{\mathrm{w}}\right)\end{array}$ & Sex & $\begin{array}{l}\% \text { of } \\
\text { catch }\end{array}$ & $\begin{array}{l}\text { TL group } \\
\text { (mm) }\end{array}$ & $\mathrm{n}_{\text {oto }}$ & TL (mm) & $\begin{array}{l}\text { Age; mean } \\
\text { hatch date }\end{array}$ \\
\hline \multirow[t]{4}{*}{23 October } & $947 ; 1860 \mathrm{~g}$ & Female & 39 & $<80$ & 17 & $59.1 \pm 7.7$ & $100 \pm 11 ; 15 \mathrm{Jul}$ \\
\hline & & & & $>80$ & 31 & $98.2 \pm 8.3$ & $111 \pm 12 ; 4 \mathrm{Jul}$ \\
\hline & & Male & 61 & $<80$ & 44 & $58.4 \pm 7.4$ & $103 \pm 10 ; 12 \mathrm{Jul}$ \\
\hline & & & & $>80$ & 9 & $89.7 \pm 7.0$ & $106 \pm 9 ; 8 \mathrm{Jul}$ \\
\hline \multirow[t]{4}{*}{20 November } & $435 ; 743 \mathrm{~g}$ & Female & 26 & $<80$ & 13 & $64.6 \pm 5.7$ & $109 \pm 10 ; 3$ Aug $^{\mathrm{a}}$ \\
\hline & & & & $>80$ & 29 & $104.0 \pm 10.2$ & $114 \pm 11 ; 29 \mathrm{Jul}^{\mathrm{a}}$ \\
\hline & & Male & 74 & $<80$ & 51 & $60.1 \pm 4.5$ & $108 \pm 11 ; 3 \mathrm{Aug}^{\mathrm{a}}$ \\
\hline & & & & $>80$ & 4 & 95.9 & $105 ; 7$ Aug $^{\mathrm{a}}$ \\
\hline \multirow[t]{4}{*}{18 December } & $211 ; 914 \mathrm{~g}$ & Female & 38 & $<90$ & 19 & $72.6 \pm 7.9$ & $115 \pm 13 ; 24$ Aug $^{\mathrm{a}}$ \\
\hline & & & & $>90$ & 24 & $106.6 \pm 10.6$ & $116 \pm 14 ; 23 \mathrm{Aug}^{\mathrm{a}}$ \\
\hline & & Male & 62 & $<90$ & 49 & $68.9 \pm 7.8$ & $112 \pm 13 ; 27$ Aug $^{\mathrm{a}}$ \\
\hline & & & & $>90$ & 4 & $102.7 \pm 9.5$ & $133 \pm 25 ; 7 \mathrm{Aug}^{\mathrm{a}}$ \\
\hline
\end{tabular}

ping films $\left(3 \mathrm{M}^{\circledR}\right)$ until daily increments along the entire reading axis were clearly visible under $400 \times$ magnification (Nikon Eclipse E400 compound microscope). Following polishing, a drop of immersion oil was placed on each otolith, which enhanced the clarity of daily growth increments within $24 \mathrm{~h}$. Otoliths were measured and read across the sagittal plane from the nucleus to the dorsal or ventral otolith edge, because the more conventional core to post-rostrum axis proved to be too curved to be reliably interpretable (Fig. S2). Along the chosen axis, daily incre- ments were readily interpretable except for a narrow zone of ambiguity at the edge, particularly for specimens collected in November and December. Cumulative increment widths showed the expected strong linear otolith-fish size relationship for both males and females $\left(\mathrm{r}^{2}=0.76, \mathrm{p}<0.001\right)$ (Fig. 1), thus indicating that otolith growth could be used as a proxy for somatic growth. Increments were enumerated and measured using Image Pro ${ }^{\circledR}$ Premier (v.9.1) connected to a Lumenera ${ }^{\circledR}$ Infinity2-2 digital camera. For each otolith section, multiple focal planes were cap-

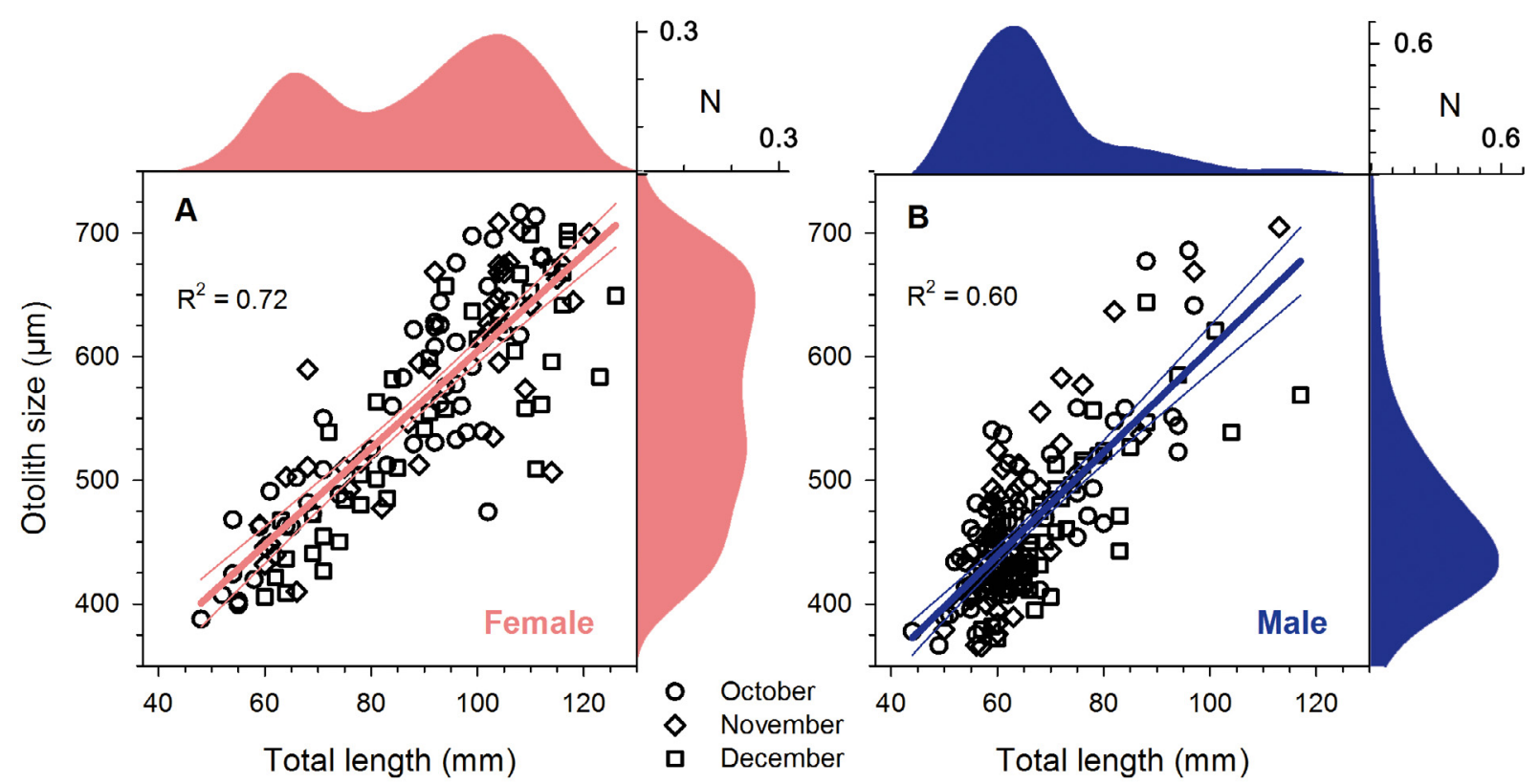

Fig. 1. Otolith size versus total length for Menidia menidia (A) females and (B) males sampled during beach seine surveys in October, November, and December 2015. Thick and thin lines: linear regression and 95\% CI, respectively; shading: relative frequency distributions of all otolith and fish sizes across collections 
tured and merged into multi-layer images to aid the reader in interpreting the otolith microstructure. The radius of the hatch-check $(\mu \mathrm{m})$ was measured. The last growth increment was presumed to be incomplete and thus excluded from growth analyses. Increment number was assumed to correspond to an individual's age in days post-hatch (dph; Barkman 1978, Barkman \& Bengtson 1987). Hatch date was calculated by subtracting age from the date of collection, while the formation date of each increment was calculated by adding the increment number to the hatch date. Precision and reader bias of otolith readings were estimated via within and across blind reader calibrations, using a $\sim 10 \%$ subsample of analyzed otoliths (30 out of 294, 10 from each collection). Between readers, the average percent error $(\mathrm{APE}$; Chang 1982, Stevenson \& Campana 1992) was $6 \%$, while the within-reader APE was $3.6 \%$. However, because age estimates from the experienced second reader (H. Baumann, 16+ yr) were on average $14 \mathrm{~d}$ higher than those of the primary reader, all age estimates were adjusted by $14 \mathrm{~d}$. A single specimen was found to possess a clear winter ring; this age-1 silverside was excluded from analysis.

\subsection{Statistical analyses}

The proportion of females $\left(\mathrm{N}_{\text {fem }} / \mathrm{N}_{\text {fem+male }}\right)$ per $10 \mathrm{~mm}$ TL class in the otolith sample was used to derive sex-specific TL distributions of the population sample (beach seine), assuming sexes were randomly sampled within each TL class. Similarly, otolith-derived hatch distributions were scaled to population by applying a scale factor (SF) to each individual based on the relative frequencies (RF) of each $10 \mathrm{~mm}$ TL class in the population vs. otolith sample for each collection ( $\left.\mathrm{SF}=\mathrm{RF}_{\text {population }} / \mathrm{RF}_{\text {otolith }}\right)$. Because both male and female TL distributions appeared to be bimodal (i.e. non-normal; see Fig. 2), sex-specific TL distributions were compared within and across collections using Kolmogorov-Smirnov (K-S) tests. To infer the plausibility of age estimates for YoY collected in October, November, and December, scaled hatch distributions were then visually compared to the expected hatch window for silversides in our area. Given the known general spawning window (1 May-15 July, Murray et al. 2017, Baumann et al. 2018), temperatures recorded on-site, and laboratory-derived estimates of temperaturedependent time-to-hatch (Murray et al. 2017), the expected hatch window encompassed the time from 15 May-21 July 2015.
We subsequently compared YoY otolith growth trajectories (i.e. widths of increments) between the 3 collections, 2 sexes, and 2 TL groups, the latter corresponding to individuals smaller/larger than $80 \mathrm{~mm}$ TL (October, November) or smaller/larger than $90 \mathrm{~mm}$ TL (December). This analysis focused on the first 60 increments (i.e. 1-60 dph) based on previous evidence for successful daily age estimation up to at least this age in M. menidia (Conover 2004). A univariate repeated-measures general linear model (RM-GLM) was set up with increment width as the dependent variable, increment number as the repeated within-subject factor $(\mathrm{n}=60)$, and collection, sex, and TL group as between-subject factors. Because both mean and variance of increment widths are known to vary with age (Barkman \& Bengtson 1987, Pepin et al. 2001), thus violating the sphericity assumption of RM-GLMs, the Greenhouse-Geisser procedure was applied to decrease the degrees of freedom and thereby reduce the probability of Type I errors.

All remaining analyses were conducted only for YoY survivors from October, because the onset of winter ring formation likely resulted in age underestimation in YoY collected in November and December (see Section 3). Scaled cumulative hatch distributions of males and females were compared visually and with a K-S test, followed by grouping individuals into each of 4 bi-weekly hatch intervals that were chosen based on sample size and the known semilunar spawning periodicity of silversides (Conover 1985). Subsequently, TL-at-age was back-calculated for each individual over the entire increment record (99-148 dph) with the biological intercept method (Campana 1990) and an assumed length at hatch of $5 \mathrm{~mm}$ (Barkman \& Bengtson 1987, Bengtson et al. 1987, Murray et al. 2014). Median back-calculated TL trajectories for each sex and TL group were then compared within each bi-weekly hatch interval.

To estimate the thermal history of October YoY, we used continuous temperature data recorded by a Manta Sub2 probe (Eureka ${ }^{\circledR}$ Water Probes) at our study site. Three small gaps in the record $(<8 \mathrm{~d})$ were linearly interpolated. Daily temperatures during a larger data gap (34 d, 18 June-22 July) were estimated via linear regression between the Mumford Cove data set and temperatures in nearby Niantic Bay (2015-2016), which were strongly correlated $\left(T_{\text {Mumford }}=1.07 \times T_{\text {Niantic }}-0.54 ; \mathrm{r}^{2}=0.92, F=6024.9\right.$, $\mathrm{p}<0.001)$. Average daily temperatures were then linked to the corresponding day of increment formation for each individual. To quantify the thermal dependency of larval growth in October YoY, we cal- 
culated the mean experienced temperature during the first $30 \mathrm{dph}$ for each individual and correlated it to its mean daily growth rate over the first $30 \mathrm{dph}$ (GR30) and its back-calculated TL at Day 30 posthatch (TL30; a proxy for the end of the larval stage). The $Q_{10}$ of temperature-dependent GR30 was calculated as:

$$
Q_{10}=\left(\frac{\mathrm{GR} 30_{2}}{\mathrm{GR} 30_{1}}\right)^{\left(\frac{10}{T_{2}-T_{1}}\right)}
$$

Finally, we selected only those dates/temperatures where individuals had a back-calculated TL between 8 and $21 \mathrm{~mm}$, which is the temperature-sensitive size window in Atlantic silversides (Conover \& Fleisher 1986). We then related the female proportion ( F / [F + $\mathrm{M}])$ to the mean experienced temperature in each biweekly hatch interval (scaled to the entire population using $\mathrm{SF}_{\text {; }}$ see above) and compared it to laboratoryderived temperature-specific sex ratios for a population of similar latitude (Conover \& Heins 1987). All statistical analyses were conducted in SPSS Statistics v.20 (IBM).

\section{RESULTS}

YoY silverside abundance decreased from October $\left(\mathrm{n}=947\right.$, wet weight $\left.\left[W_{\mathrm{w}}\right]=1.9 \mathrm{~kg}\right)$ to November $(\mathrm{n}=$ $\left.435, W_{\mathrm{w}}=0.7 \mathrm{~kg}\right)$ to December $2015\left(\mathrm{n}=211, W_{\mathrm{w}}=\right.$ $0.9 \mathrm{~kg}$ ), while the range of the TL distributions shifted surprisingly little (Fig. 2). In all 3 collections, females were less abundant than males (Oct: $39 \%$; Nov: $26 \%$; Dec: $38 \%$ of the catch), but their proportions increased linearly with TL, from $0-26 \%$ female at $40-$ $50 \mathrm{~mm}$ TL to $70-100 \%$ female at sizes $>100 \mathrm{~mm}$ TL (Fig. 2). Across collections, both sexes had bimodal size distributions that allowed distinguishing a small from a large TL group (October, November: $<80$, $>80 \mathrm{~mm}$ TL, December: <90, >90 mm TL, respectively;
Fig. 2). TL distributions differed significantly between sexes (K-S $=2.70-4.00, \mathrm{p}<0.001$ for all collections), because small and large females were approximately evenly represented ( $\sim 60$ and $\sim 40 \%$, respectively), whereas males were overwhelmingly in the small TL group (>94\%).

The hatch distribution of October YoY (28 May-16 July) aligned well with the expected hatch window (15 May-21 July), whereas November and December hatch distributions of both sexes were shifted progressively into summer outside the expected hatch window (Fig. 3). This indicated progressive age underestimation due to indiscernible increments at the otolith edge likely caused by the onset of winter ring formation.

When otolith growth trajectories over the initial $60 \mathrm{dph}$ were analyzed separately for each collection, sex, and TL group, the pattern in all collections suggested the existence of 2 distinct growth phenotypes: one that reached average peak increment widths of approximately $6 \mu \mathrm{m}$ at $30-40 \mathrm{dph}$, and a second with average peak increment widths of approximately $8 \mu \mathrm{m}$ at 40-50 dph (Fig. 4). Importantly, while both growth phenotypes were about equally represented in female YoY, almost all males were of the slow-growing phenotype (94-98\%) (Fig. 4). A univariate RM-GLM confirmed this by detecting significant effects of collection $(p<0.001)$ and TL group ( $p<0.001)$, but no effects of sex $(p=0.67)$ on increment widths (Table 2). In other words, small females grew as slowly as small males, and large females grew as fast as large males, but there were simply many more fast-growing females than males in all YoY collections.

For October YoY only, we examined the 2 growth phenotypes in further detail by back-calculating individual length-at-age trajectories for small/large females and males separately for each of the 4 bi-
Fig. 2. Relative total length (TL) frequencies of young-of-year female and male Menidia menidia collected during 3 surveys in fall 2015. Grey circles: proportion of females per $10 \mathrm{~mm}$ TL class

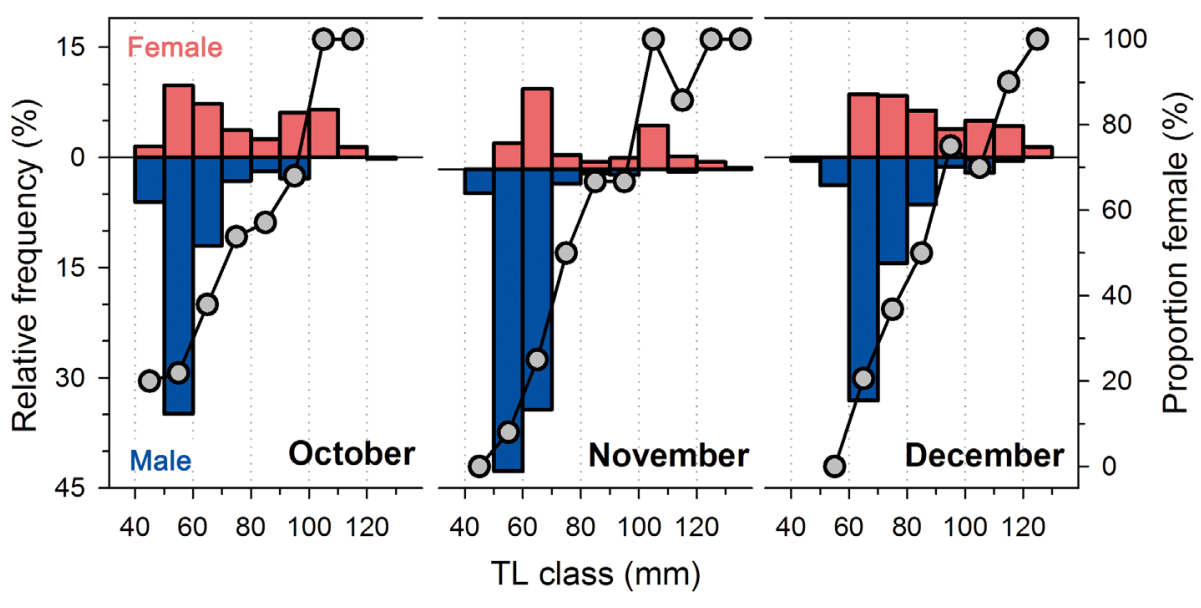




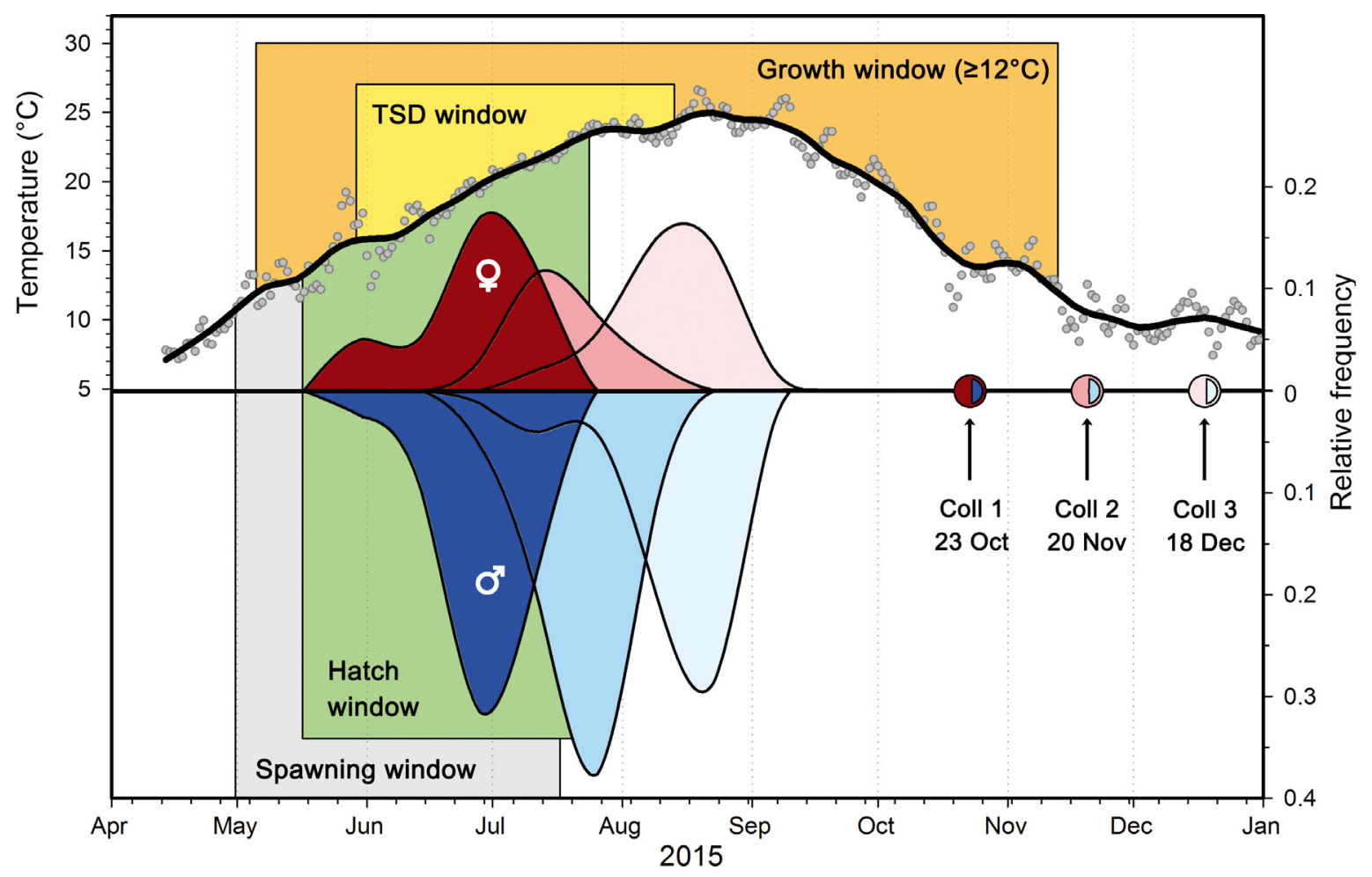

Fig. 3. Expected hatch window versus otolith-derived hatch distributions of young-of-year (YoY) Menidia menidia collected in October, November, and December 2015. In our study area, M. menidia generally spawn 1 May-15 July (grey shading), which corresponds to an expected hatch window of 15 May-21 July (green shading). Hence, the hatch distribution of October YoY was consistent with the expected window, while the shifts into summer in the November and December distributions indicated progressive age underestimation due to beginning winter ring formation. Small grey circles: average daily water temperatures at our study site; thick black line: LOESS smoother. The approximate extent of the temperature-sensitive window for sexdetermination (TSD; 8-21 mm) was derived from M. menidia growth rates in the lab (Conover \& Present 1990). Orange shading: window of possible growth, given the known thermal growth threshold for this species (Baumann \& Conover 2011); half-circles: corresponding YoY sampling dates

weekly hatch intervals. First, this showed that fastand slow-growing phenotypes indeed arose from common hatch intervals. Second, females in the earliest hatch interval were 3 times more abundant than males and mostly of the fast-growing phenotype (Fig. 5). Cumulative hatch frequency distributions of small males vs. small females were not significantly different ( $\mathrm{K}-\mathrm{S}=1.30, \mathrm{p}=0.07)$, but those of large males vs. large females were $(\mathrm{K}-\mathrm{S}=1.40, \mathrm{p}=0.04)$. Large females were on average 11,8 , and $4 \mathrm{~d}$ older than small females, small males, and large males, respectively (Fig. 6). Back-calculated TL30 increased with increasing hatch interval and mean temperature, from $12-25 \mathrm{~mm}$ for small females, $19-30 \mathrm{~mm}$ for large females, 12-23 $\mathrm{mm}$ for small males, and 23$30 \mathrm{~mm}$ large males, with corresponding GR30 values ranging between 0.23 and $0.83 \mathrm{~mm} \mathrm{~d}^{-1}$. The temperature-dependent increase in GR30 was similar between the groups $\left(0.075 \mathrm{~mm} \mathrm{~d}^{-1}{ }^{\circ} \mathrm{C}^{-1}\right)$ and had a $Q_{10}$ value of 4.7 (Fig. 7).
Across the 4 bi-weekly hatch intervals, female proportions were unrelated to the estimated temperature that October survivors experienced during their sex-determining size window (Pearson bivariate correlation, $\mathrm{p}=0.28$ ) (Fig. 8). All female proportions

Table 2. Univariate repeated-measure general linear model testing for effects of collection month (October, November, December), sex (female, male), and total length (TL) group (October, November: <80, >80 mm TL; December: <90, $>90 \mathrm{~mm}$ TL) on the width of the first 60 young-of year otolith increments (60 d post-hatch). Partial eta ${ }^{2}\left(\eta_{\mathrm{p}}{ }^{2}\right)$ : proportion of variance explained. Data were adjusted by the GreenhouseGeisser procedure

\begin{tabular}{|lrrcr|}
\hline & df & \multicolumn{1}{c}{$F$} & $\mathrm{p}$ & \multicolumn{1}{c|}{$\eta_{\mathrm{p}}{ }^{2}$} \\
\hline Increment & 4.37 & 383.76 & $<0.001$ & 0.57 \\
Collection & 8.75 & 4.30 & $<0.001$ & 0.03 \\
Sex & 4.37 & 0.61 & 0.67 & 0.002 \\
TL group & 4.37 & 28.39 & $<0.001$ & 0.89 \\
\hline
\end{tabular}



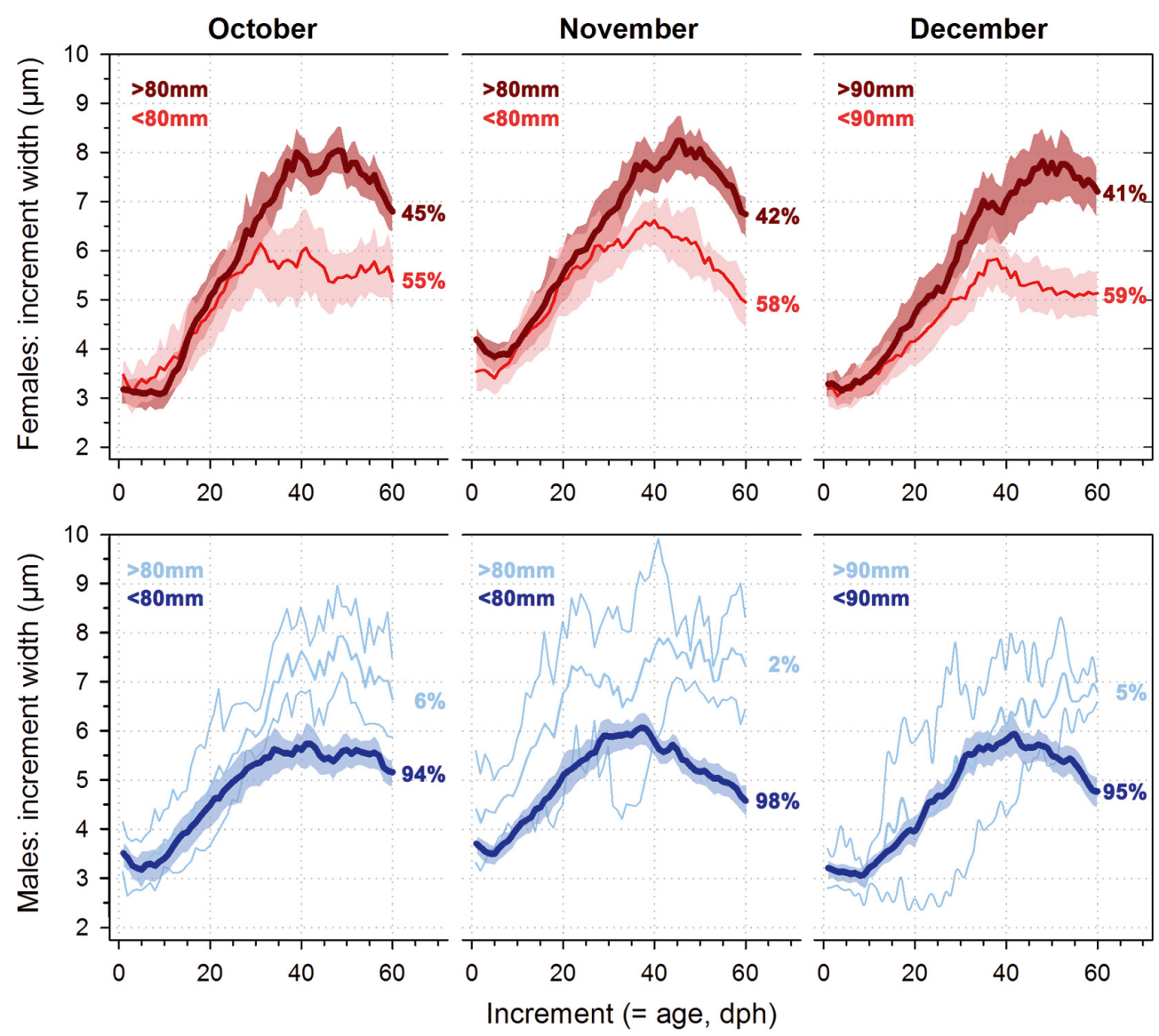

Fig. 4. Mean width (lines) $\pm 95 \%$ bootstrapped CIs (shading) of the first 60 otolith increments in large female (dark red, shading) vs. small female (light red, shading) young-of-year (YoY) Menidia menidia, and large male (light blue lines) vs. small male YoY (dark blue, shading) sampled in October, November, and December 2015. Percentage values denote scaled proportions of small vs. large individuals caught in October, November $(<80,>80 \mathrm{~mm}$ total length [TL]), and December $(<90,>90 \mathrm{~mm}$ TL).

For clarity, shading was omitted for large males due to their small number. Dph: days post-hatch

were higher than expected from experimental TSD values alone (Conover \& Heins 1987), because October YoY experienced a range of $19.2-23.4^{\circ} \mathrm{C}$ during their sex-determining size window, but instead of $\sim 10-20 \%$ female (laboratory), they exhibited female proportions of $35-66 \%$ (mean $=44 \%$ ) (Fig. 8). On average, the sex-determining size window lasted from 8$29 \mathrm{dph}$ and shortened length with increasing hatch intervals.

\section{DISCUSSION}

We used otolith microstructure analysis in YoY Atlantic silversides Menidia menidia to examine sexspecific growth characteristics of survivors sampled at the end of their growing season (Conover 1984). While it was previously assumed that silverside otoliths cannot be aged accurately beyond the early juvenile stage $(<60 \mathrm{dph}$; Conover 2004), our study suggests that otolith microstructure analysis is applicable to older juveniles ( $>4 \mathrm{mo}$ ), but only until fall water temperatures decline below the species' thermal growth threshold of $12^{\circ} \mathrm{C}$ (Conover \& Present 1990, Baumann \& Conover 2011). This is because survivors from October had 99-148 daily increments that corresponded to a hatch distribution consistent with the expected hatch window (Fig. 3), whereas hatch distributions from November and December YoY fell outside of this window, indicating age underestimation. Temperature records from the study site supported this conclusion, by showing that fall temperatures declined below $12^{\circ} \mathrm{C}$ in early November (Fig. 3), hence impeding further somatic growth and rendering further otolith increments indiscernible. Our findings therefore suggest that silversides in our area begin winter ring formation in their otoliths around the end of October, which was previously unknown. The general extent of the silverside spawning window in our study area (eastern Long Island 

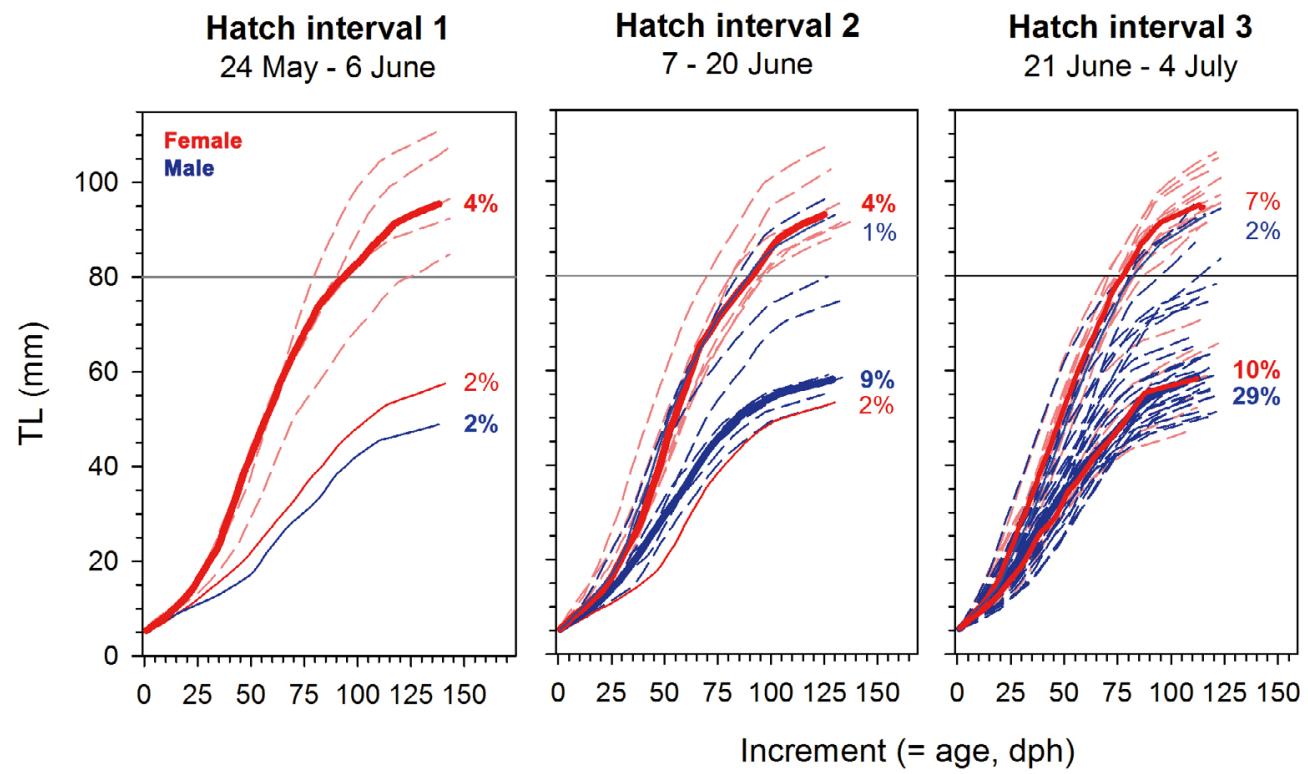

\section{Hatch interval 4 \\ 5 - 18 July}

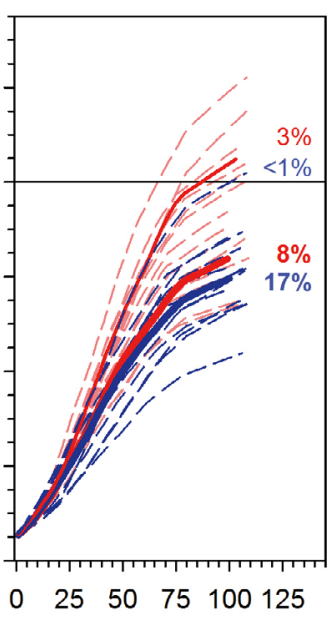

Fig. 5. Back-calculated total length (TL)-at-age of female and male young-of-year Menidia menidia survivors hatched during 4 bi-weekly hatch intervals and sampled in October 2015. Dashed lines: individual trajectories; solid lines: median trajectories of the large (>80 mm TL) vs. small $(<80 \mathrm{~mm} \mathrm{TL})$ size group at the time of catch. Percentage values correspond to scaled catch proportions of each size group. Dph: days post-hatch

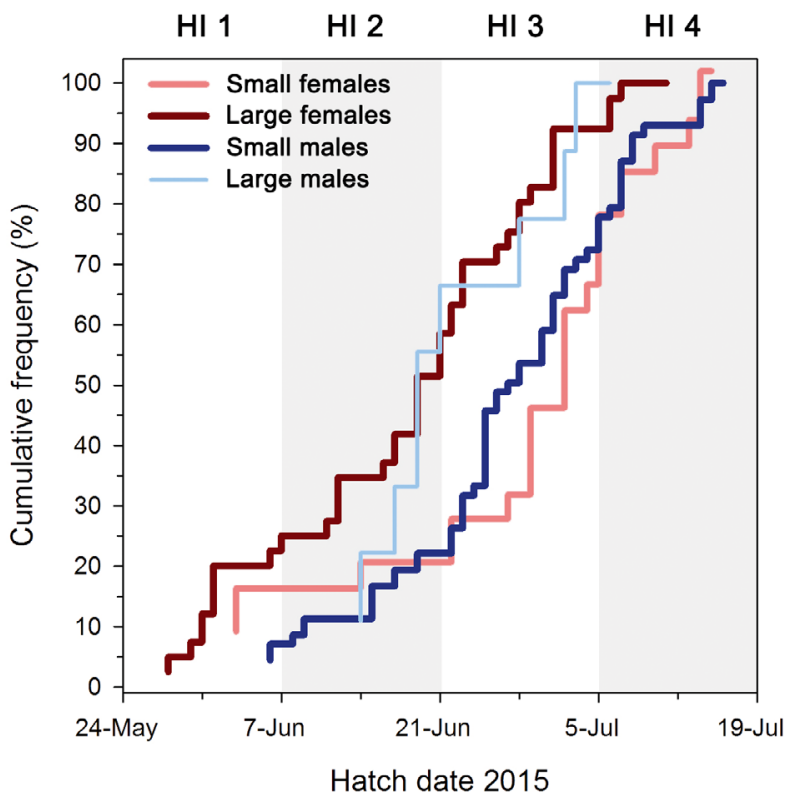

Fig. 6. Cumulative hatch frequency distributions of small and large female and male young-of-year Menidia menidia collected in October 2015. White/grey shading: 4 hatch intervals ( $\mathrm{HI}$; dates given in Fig. 5) used in subsequent analyses

Sound) is well established and has been repeatedly confirmed by our experimental work with silverside embryos strip-spawned from wild adults caught throughout the spawning season (Murray et al. 2014, Depasquale et al. 2015, Baumann et al. 2018, Murray \& Baumann 2018). Specifically, in 2015 we recorded

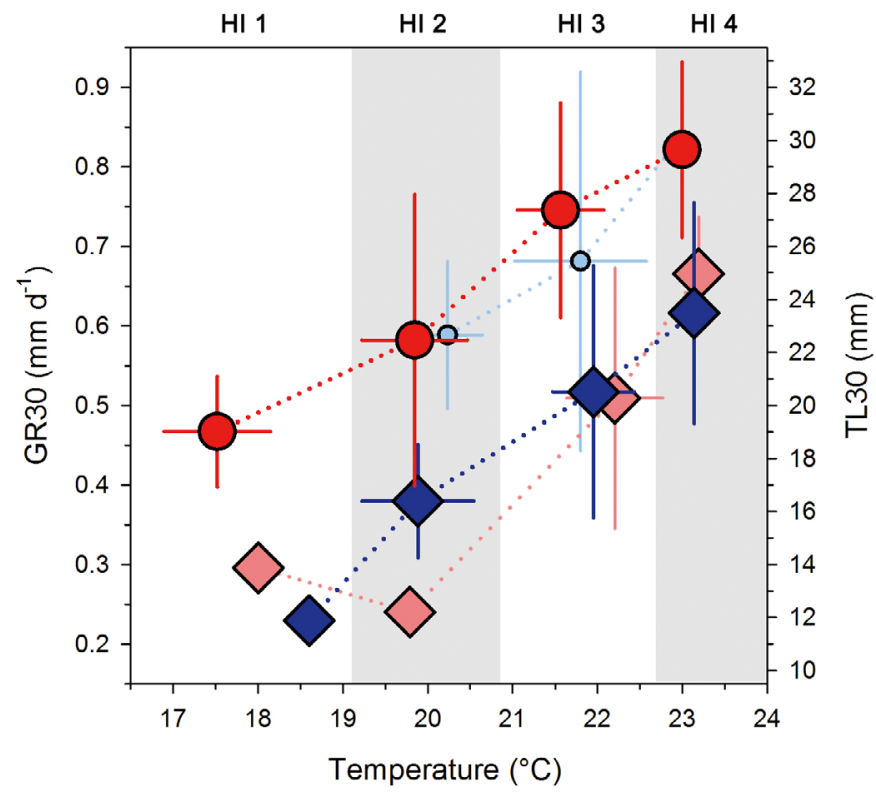

Fig. 7. Back-calculated mean $( \pm \mathrm{SD})$ growth rates (GR30) and total length (TL30) during the first $30 \mathrm{~d}$ post-hatch of Menidia menidia in relation to the mean $( \pm \mathrm{SD})$ experienced temperature of female (red) and male (blue) young-of-year survivors hatched during 4 bi-weekly hatch intervals ( $\mathrm{HI}$; dates given in Fig. 5) sampled in October 2015. Circles and diamonds: individuals $>80$ and $<80 \mathrm{~mm}$ TL at catch. Symbol size approximates the proportion of each size group

the first appearance of ripe silverside adults in Mumford Cove on 1 May, which were strip-spawned on 3 May and their offspring hatched on 16 May after de- 


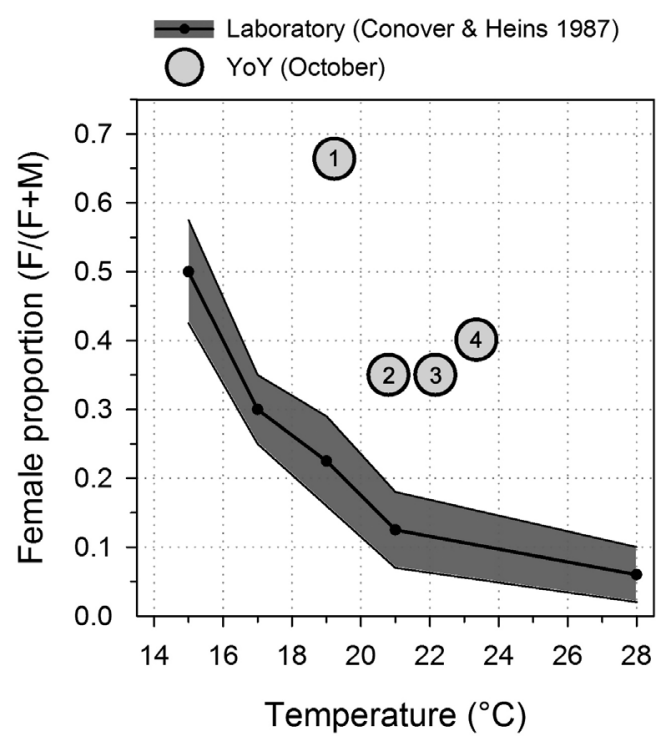

Fig. 8. Temperature-dependent Menidia menidia female proportions in laboratory trials (mean $\pm 95 \% \mathrm{CI}$ : black line and shading, respectively) (Conover \& Heins 1987) vs. female proportions in young-of-year (YoY) sampled in October. Circles: individuals grouped into 4 bi-weekly hatch intervals (HI; dates given in Fig. 5) for which proportion of females and temperatures experienced during the sex-determining size window $(8-21 \mathrm{~mm})$ were estimated

veloping at slightly higher water temperatures $\left(17^{\circ} \mathrm{C}\right.$; Murray et al. 2017) than in the wild at that time $\left(\sim 13^{\circ} \mathrm{C}\right)$ (Fig. 3).

Sex-specific size and growth distributions of YoY silversides presented the most intriguing part of this study. Both female and male TL distributions were technically bimodal, but females split about evenly into 2 TL groups, whereas small males were so dominant that TL distributions appeared almost unimodal. What caused this pattern? We confidently ruled out potential misidentification of sexes, because older YoY silversides have already well-developed (if unripe) and easily distinguishable gonads. We also ruled out potential confusion with the smaller congener $M$. beryllina, based on counts of anal fin rays in a subsample of small individuals indicating $100 \% \mathrm{M}$. menidia (Middaugh et al. 1987). The upper estuarine $M$. beryllina is almost never encountered in full strength seawater habitats like Mumford Cove.

A common reason for bimodal size distributions in fish is the existence of different age cohorts (e.g. McBride \& Conover 1991, Neuman et al. 2001, Morley et al. 2007). In our case, large females from October were marginally older than their small male or female conspecifics, which is consistent with TSD in this species (Conover \& Kynard 1981, Conover \& Heins 1987, Hice et al. 2012). However, the small age differ- ences alone cannot explain the large dimorphic pattern. In addition, if size differences were simply generated by age differences, one would expect relatively homogenous growth patterns. In contrast, our study detected 2 distinct growth phenotypes in the increment widths of YoY survivors across collections, and for YoY silversides from October, we further demonstrated that fast- and slow-growing phenotypes arose from within the same bi-weekly hatch intervals. Different age cohorts would also be inconsistent with the annual life history of this species, which spawns with semilunar periodicity from the time spring temperatures in nearshore habitats exceed $16^{\circ} \mathrm{C}$ (Middaugh et al. 1987) until they die. There is no good adaptive reason for an annual fish to delay spawning. We conclude that bimodal size distributions were primarily the result of divergent YoY growth phenotypes, and less due to differences in age.

The apparent co-occurrence of divergent growth phenotypes strongly suggests genetic growth differences in this silverside population. Given their comparable ages, large and small YoY from October likely experienced similar temperatures, food levels, and predator fields. Large-scale immigration or emigration of YoY silversides in or out of the study area is unlikely, because the species remains in nearshore habitats throughout the growing season until their overwinter migration begins in late fall (Middaugh et al. 1987). Under common garden conditions, phenotypic differences are genotypic differences (Conover \& Baumann 2009) that may have produced the divergent growth phenotypes in silversides.

Two further arguments support this conclusion. First, the intermediate position of Long Island Sound within the species' latitudinal range has previously been shown to correspond to intermediate levels of TSD, vertebral number, and growth plasticity in these silverside populations (Conover \& Present 1990, Yamahira et al. 2006, Hice et al. 2012). The species' offshore winter migration likely promotes considerable gene flow and could therefore mix slower growing genotypes from southern populations with faster growing genotypes from more northern populations prior to their spring ingression into their nearshore spawning grounds (Clarke et al. 2010, Mach et al. 2011). The second argument involves TSD itself, specifically that it is never uniformly expressed among all individuals of a population. Even in southernmost populations with the highest levels of TSD, $20-30 \%$ of individuals still exhibit the alternative, genetic sex determination (GSD; Hice et al. 2012, Duffy et al. 2015). In our latitudes, previous experimental work concluded that $\sim 40 \%$ of individuals 
have reduced temperature-sex sensitivity (Duffy et al. 2015). It is therefore possible that a fraction of silversides in our study area expressed GSD, thereby producing balanced ratios of males and females that experienced similar conditions and therefore expressed similar growth trajectories. Conversely, the fraction of the silverside population expressing TSD would have produced male-biased sex ratios and genetically faster growing females than males. Growth-dependent sexual size dimorphism is common in fishes (Parker 1992, Munday et al. 2004, Walker \& McCormick 2004), but for silversides the empirical evidence is equivocal. A previous laboratory study did not detect sex-specific growth differences in early juveniles ( $20 \mathrm{~mm}$; Conover \& Kynard 1981), while a more recent long-term experiment indeed found faster female than male growth, but size differences between sexes became only statistically detectable in older juveniles $>50 \mathrm{~mm}$ (C. S. Murray et al. unpubl. data).

Growth and mortality are generally inversely related during fish early life stages, because the window of highest predation mortalities is shorter for faster growing cohorts (stage-duration hypothesis; Leggett \& Deblois 1994, Houde 1997, Robert et al. 2007) and because larger individuals generally escape predators better (bigger-is-better hypothesis; Meekan \& Fortier 1996, Paradis et al. 1996, Hare \& Cowen 1997, Takasuka et al. 2003). If selective mortality is biased against smaller, slower growing individuals, then large, faster growing female silversides would have higher survival probabilities than their small, slower growing male and female conspecifics. This in turn implies that initial sex ratios in silverside offspring would change over the course of the growing season, such that YoY survivors in fall have higher than expected female proportions. Hence, the observed uneven distribution of growth phenotypes in this silverside population directly predicts the selective disappearance of male over female silversides.

Detecting selective mortality patterns in YoY fish generally requires at least 2 population samples over time, but in the case of silversides there is an indirect alternative that employs the evolutionary phenomenon of TSD. TSD is empirically so well documented in this species that temperature-specific estimates of female proportions exist for many populations across its distributional range (Conover \& Heins 1987, Hice et al. 2012). This allowed us to contrast observed sex ratios in October YoY with predicted sex ratios based on those published laboratory values corresponding to the reconstructed YoY thermal histories. This revealed that sex ratios were male-biased; but much less so than predicted, and they were unrelated to reconstructed temperature. The more balanced sex ratio of silversides at the end of their growing season therefore comprises independent evidence for the suggested selective removal of male over fast-growing female phenotypes during the growing season. Male-biased mortality has been reported for other fish species (e.g. Oncorhynchus nerka; Quinn \& Buck 2001), and in silversides likely acts to equalize initially skewed sex ratios produced by TSD (Conover \& Kynard 1981). In addition, size selection also occurs during the offshore overwintering phase, where again smaller males should experience higher mortalities than large females and thus become further equalized in proportion prior to the new spawning season (Schultz et al. 1998).

In conclusion, we found that otolith microstructure analysis can be applied to YoY silversides at the end of their growing season, but is of limited value after temperatures decline below the species' thermal growth threshold and onset of winter ring formation. Growth reconstructions of male and female YoY silversides (October) allowed quantification of temperaturedependent early growth suggesting that growth- and therefore sex-selective mortality modifies the characteristics of YoY survivors throughout the spawning season. Further studies on other populations across local and larger latitudinal scales are required to corroborate these patterns. This will lead to a better understanding of selection and trade-offs between fast female growth and fitness in this and potentially other fish species.

Data archive. Pringle, JW, Baumann H (2019) Otolith microstructure of young-of-year Atlantic silversides (Menidia menidia) from Mumford Cove during 2015. Biological and Chemical Oceanography Data Management Office (BCODMO). Dataset version 2019-11-20. doi:10.1575/1912/bcodmo.782247.1.

Acknowledgements. We thank C. Murray, J. Snyder, E. Cross, C. Concannon, and all undergraduates of the Baumann lab for keeping up the bi-weekly seine survey in Mumford Cove. E. Schultz and C. Matassa provided valuable feedback on the thesis of J.W.P., and D. Conover on an earlier version of the manuscript. This study was funded by a National Science Foundation grant (OCE\#1536165) to H.B. and additional support to J.W.P. from the Department of Marine Sciences at the University of Connecticut.

\section{LITERATURE CITED}

Anderson JT (1988) A review of size dependent survival during pre-recruit stages of fishes in relation to recruitment. J Northwest Atl Fish Sci 8:55-66 
Bailey KM, Houde ED (1989) Predation on eggs and larvae of marine fishes and the recruitment problem. Adv Mar Biol 25:1-83

* Barkman RC (1978) The use of otolith growth rings to age young Atlantic silversides, Menidia menidia. Trans Am Fish Soc 107:790-792

Barkman R, Bengtson D (1987) The record of daily growth in otoliths of Atlantic silversides, Menidia menidia, from field and laboratory. J Fish Biol 31:683-695

Baumann H, Conover DO (2011) Adaptation to climate change: contrasting patterns of thermal-reaction-norm evolution in Pacific versus Atlantic silversides. Proc R Soc B 278:2265-2273

* Baumann H, Hinrichsen HH, Voss R, Stepputtis D, Grygiel W, Clausen LW, Temming A (2006) Linking growth to environmental histories in central Baltic young-of-theyear sprat, Sprattus sprattus: an approach based on otolith microstructure analysis and hydrodynamic modelling. Fish Oceanogr 15:465-476

Baumann H, Voss R, Hinrichsen HH, Mohrholz V, Schmidt JO, Temming A (2008) Investigating the selective survival of summer- over spring-born sprat, Sprattus sprattus, in the Baltic Sea. Fish Res 91:1-14

*Bamann H, Cross EL, Murray CS (2018) Robust quantification of fish early life $\mathrm{CO}_{2}$ sensitivities via serial experimentation. Biol Lett 14:20180408

* Bengtson D, Barkman R, Berry W (1987) Relationships between maternal size, egg diameter, time of spawning season, temperature, and length at hatch of Atlantic silverside, Menidia menidia. J Fish Biol 31:697-704

Campana SE (1990) How reliable are growth back-calculations based on otoliths? Can J Fish Aquat Sci 47:2219-2227

* Chang WYB (1982) A statistical method for evaluating the reproducibility of age determination. Can J Fish Aquat Sci 39:1208-1210

Clarke LM, Munch SB, Thorrold SR, Conover DO (2010) High connectivity among locally adapted populations of a marine fish (Menidia menidia). Ecology 91:3526-3537

Conover DO (1984) Adaptive significance of temperaturedependent sex determination in a fish. Am Nat 123: 297-313

Conover DO (1985) Field and laboratory assessment of patterns in fecundity of a multiple spawning fish: the Atlantic silverside, Menidia menidia. Fish Bull 83:331-341

Conover DO (2004) Temperature-dependent sex determination in fishes. In: Valenzuela N, Lance VA (eds) Temperature-dependent sex determination in vertebrates. Smithsonian Institution, Washington, DC, p 11-20

Conover DO, Baumann H (2009) The role of experiments in understanding fishery-induced evolution. Evol Appl 2: 276-290

* Conover DO, Fleisher MH (1986) Temperature-sensitive period of sex determination in the Atlantic silverside, Menidia menidia. Can J Fish Aquat Sci 43:514-520

* Conover DO, Heins SW (1987) Adaptive variation in environmental and genetic sex determination in a fish. Nature 326:496-498

Conover DO, Kynard BE (1981) Environmental sex determination: interaction of temperature and genotype in a fish. Science 213:577-579

Conover DO, Kynard BE (1984) Field and laboratory observations of spawning periodicity and behavior of a northern population of the Atlantic silverside, Menidia menidia (Pisces: Atherinidae). Environ Biol Fishes 11: 161-171
Conover DO, Munch SB (2002) Sustaining fisheries yields over evolutionary time scales. Science 297:94-96

Conover DO, Present TMC (1990) Countergradient variation in growth rate: compensation for length of the growing season among Atlantic silversides from different latitudes. Oecologia 83:316-324

Conover DO, Ross MR (1982) Patterns in seasonal abundance, growth and biomass of the Atlantic silverside, Menidia menidia, in a New England estuary. Estuaries 5: 275-286

Conover DO, Duffy TA, Hice LA (2009) The covariance between genetic and environmental influences across ecological gradients: reassessing the evolutionary significance of countergradient and cogradient variation. Ann NY Acad Sci 1168:100-129

*Depasquale E, Baumann H, Gobler CJ (2015) Variation in early life stage vulnerability among Northwest Atlantic estuarine forage fish to ocean acidification and low oxygen. Mar Ecol Prog Ser 523:145-156

* Duffy TA, Hice LA, Conover DO (2015) Pattern and scale of geographic variation in environmental sex determination in the Atlantic silverside, Menidia menidia. Evolution 69: 2187-2195

Friedland KD, Leaf RT, Kristiansen T, Large SI (2015) Layered effects of parental condition and larval survival on the recruitment of neighboring haddock stocks. Can J Fish Aquat Sci 72:1672-1681

*Gagliano M, McCormick MI, Meekan MG (2007) Survival against the odds: ontogenetic changes in selective pressure mediate growth-mortality trade-offs in a marine fish. Proc R Soc B 274:1575-1582

*Hare JA, Cowen RK (1997) Size, growth, development, and survival of the planktonic larvae of Pomatomus saltatrix (Pisces: Pomatomidae). Ecology 78:2415-2431

*Hice LA, Duffy TA, Munch SB, Conover DO (2012) Spatial scale and divergent patterns of variation in adapted traits in the ocean. Ecol Lett 15:568-575

Houde ED (1997) Patterns and consequences of selective processes in teleost early life histories. In: Chambers RC, Trippel EA (eds) Early life history and recruitment in fish populations. Springer, Dordrecht, p 173-196

K Lankford TE, Billerbeck JM, Conover DO (2001) Evolution of intrinsic growth and energy acquisition rates. II. Trade-offs with vulnerability to predation in Menidia menidia. Evolution 55:1873-1881

* Leggett WC, Deblois E (1994) Recruitment in marine fishes: Is it regulated by starvation and predation in the egg and larval stages? Neth J Sea Res 32:119-134

* Mach ME, Sbrocco EJ, Hice LA, Duffy TA, Conover DO, Barber PH (2011) Regional differentiation and postglacial expansion of the Atlantic silverside, Menidia menidia, an annual fish with high dispersal potential. Mar Biol 158:515-530

McBride RS, Conover DO (1991) Recruitment of young-ofthe-year bluefish Pomatomus saltatrix to the New York Bight: variation in abundance and growth of spring- and summer-spawned cohorts. Mar Ecol Prog Ser 78:205-216

* Meekan MG, Fortier L (1996) Selection for fast growth during the larval life of Atlantic cod Gadus morhua on the Scotian Shelf. Mar Ecol Prog Ser 137:25-37

Middaugh DP, Hemmer MJ, Goodman LR (1987) Methods for spawning, culturing and conducting toxicity-tests with early life stages of four atherinid fishes: the inland silverside, Menidia beryllina, Atlantic silverside, $M$. menidia, tidewater silverside, $M$. peninsulae and Califor- 
nia grunion, Leuresthes tenuis. US Environmental Protection Agency, Washington, DC

Morley JW, Buckel JA, Lankford TE Jr (2007) Winter energy storage dynamics and cohort structure of young-of-theyear bluefish Pomatomus saltatrix off North Carolina. Mar Ecol Prog Ser 334:273-286

Munday PL, Hodges AL, Choat JH, Gust N (2004) Sex-specific growth effects in protogynous hermaphrodites. Can J Fish Aquat Sci 61:323-327

Murray CS, Baumann H (2018) You better repeat it: complex temperature $\times \mathrm{CO}_{2}$ effects in Atlantic silverside offspring revealed by serial experimentation. Diversity (Basel) 10:69

Murray CS, Malvezzi AJ, Gobler CJ, Baumann H (2014) Offspring sensitivity to ocean acidification changes seasonally in a coastal marine fish. Mar Ecol Prog Ser 504:1-11

Murray CS, Fuiman L, Baumann H (2017) Consequences of elevated $\mathrm{CO}_{2}$ exposure across multiple life stages in a coastal forage fish. ICES J Mar Sci 74:1051-1061

Neuman M, Witting D, Able K (2001) Relationships between otolith microstructure, otolith growth, somatic growth and ontogenetic transitions in two cohorts of windowpane. J Fish Biol 58:967-984

Otterlei E, Folkvord A, Nyhammer G (2002) Temperaturedependent otolith growth of larval and early juvenile Atlantic cod (Gadus morhua). ICES J Mar Sci 59:851-860

Paradis A, Pepin P, Brown J (1996) Vulnerability of fish eggs and larvae to predation: review of the influence of the relative size of prey and predator. Can J Fish Aquat Sci 53:1226-1235

Parker G (1992) The evolution of sexual size dimorphism in fish. J Fish Biol 41:1-20

* Pepin P, Dower JF, Benoit HP (2001) The role of measurement error on the interpretation of otolith increment width in the study of growth in larval fish. Can J Fish Aquat Sci 58:2204-2212

Editorial responsibility: Stylianos Somarakis, Heraklion, Greece
Peterson I, Wroblewski J (1984) Mortality rate of fishes in the pelagic ecosystem. Can J Fish Aquat Sci 41:1117-1120

Quinn TP, Buck GB (2001) Size and sex selective mortality of adult sockeye salmon: bears, gulls, and fish out of water. Trans Am Fish Soc 130:995-1005

Robert D, Castonguay M, Fortier L (2007) Early growth and recruitment in Atlantic mackerel Scomber scombrus: discriminating the effects of fast growth and selection for fast growth. Mar Ecol Prog Ser 337:209-219

Schultz ET, Conover DO, Ehtisham A (1998) The dead of winter: size-dependent variation and genetic differences in seasonal mortality among Atlantic silverside (Atherinidae: Menidia menidia) from different latitudes. Can J Fish Aquat Sci 55:1149-1157

Stevenson DK, Campana SE (1992) Otolith microstructure examination and analysis. Can Spec Publ Fish Aquat Sci 117:1-126

Takasuka A, Aoki I, Mitani I (2003) Evidence of growthselective predation on larval Japanese anchovy Engraulis japonicus in Sagami Bay. Mar Ecol Prog Ser 252:223-238

* Therkildsen NO, Wilder AP, Conover DO, Munch SB, Baumann H, Palumbi SR (2019) Contrasting genomic shifts underlie parallel phenotypic evolution in response to fishing. Science 365:487-490

*Vaudrey JM, Kremer JN, Branco BF, Short FT (2010) Eelgrass recovery after nutrient enrichment reversal. Aquat Bot 93:237-243

Walker SPW, McCormick MI (2004) Otolith-check formation and accelerated growth associated with sex change in an annual protogynous tropical fish. Mar Ecol Prog Ser 266: 201-212

* Yamahira K, Lankford TE, Conover DO (2006) Intra- and interspecific latitudinal variation in vertebral number of Menidia spp. (Teleostei: Atherinopsidae). Copeia 2006: 431-436

Submitted: April 23, 2019; Accepted: October 21, 2019 Proofs received from author(s): December 2, 2019 